Copyright (C)2015

Australian and New Zealand Journal of European Studies http://www.eusanz.org/ANZJES/index.html

Vol.6(2)-7(1)

ISSN 1837-2147 (Print)

ISSN 1836-1803 (Online)

\title{
Considering the Eurozone Crisis
}

\author{
Stuart Bruce \\ Monash University, Clayton
}

In light of the Eurozone crisis, how essential is the current incarnation of the Economic and Monetary Union (EMU) for prosperity in Europe and how can understanding the causes of the crisis inform potential adaptations?

\section{Introduction}

The Eurozone crisis is proving highly instructive for the study of ideological constructs and their key impact on political discourse and economic systems. Lynn (2011) argues that the Eurozone crisis has the potential to "turn the European Union into a dark, oppressive force ... demanding cuts and austerity for its members, imposing taxes they don't want to pay, and lengthening recessions that already look severe enough ... Slowly but surely that will undermine [the EU's] public legitimacy

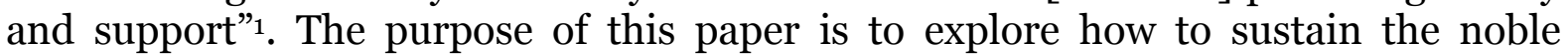
project of a political union in Europe by understanding the economic problems and ideologies that threaten to undermine it.

This paper will unfold in three sections and aims to address, in parallel, the economic and political dimensions of the EMU crisis. First, I will explore the original arguments for an EMU and compare the economic assumptions and results against a backdrop of economic theory. This will shed light on whether it is worth the extraordinary pain needed to preserve the current policies of the Eurozone. The second section will outline the history of the crisis and explore the political dimensions of the economic causes and responses. I will then lead into the third section with a normatively-framed exposition of the main options for crisis recovery with a focus on managing bailouts and the role of Keynesian stimulus. 


\section{Testing The Arguments For An EMU}

The formative years of the EMU saw support for pan-European federalism override any thorough exploration of the economic risks involved with a single currency ${ }^{2}$. The evidence points to the fact that the single currency was introduced as a political mechanism - to be a driver, not a symptom, of economic union. The Delors Committee appeared as the central driving force behind the federalist push for a single currency - producing the Delors Report (1989) and One Market, One Money (1990). The Delors Report was based on the Werner Report of the 1970 s and created the political edifice for the Maastricht Treaty (or Treaty for the European Union) wherein lay the project of the EMU and single currency. One Market, One Money was produced to lend intellectual authority to the single currency project:

One Market, One Money was heavily flawed, claiming to address both the benefits and costs of EMU yet "costs" were defined in terms of costs forgone - actually just more benefits, e.g. how "costs of inflation" 3 and "in-house costs" 4 would be reduced under an EMU. Its main assertions were that "asymmetric shocks...were likely to diminish with the disappearance of trade barriers" 5 and the completion of the single currency and this was because of greater wage flexibility ${ }^{6}$ and intra-industry trade ${ }^{7}$. The report also asserted that it would not be costly to relinquish a national currency because currency devaluation would not be needed. It even criticised currency devaluation in times of shock because it supposedly delivers "poorer results in terms of inflation ... dissipation of the employment gains" and will "slow down the adjustment process of the economy to equilibrium"8. This is a clear example of theoretical overreach caused by the politicisation of the study. Devaluing a currency would indeed cause higher inflation, yet as long as it was kept to around $4-5 \%$, this would not be "poorer results" but actually provide a boost to the economy and lower the burden of debt 9 . In terms of a slower return to equilibrium, the assumption is that an economy will recover faster by keeping the currency high and forcing wages down, instead of letting the currency devalue. The report ignores the fact that forcing down real wages can cause real deflation across the whole economy leading to spiralling feedback cycles of lowering demand, increasing real debt and unemployment - a disastrous outcome ${ }^{10}$. The fact that it premises a single currency on the belief that in times of shock a nation can simply lower wages - what became known as 'internal deflation' in 'eurospeak' - demonstrates its lack of economic

\footnotetext{
${ }^{2}$ For an exploration of pan-European federalism see Michelle Cini and Nieves Pérez-Solórzano Borragán, European Union politics, 3rd ed. (Oxford ; New York: Oxford University Press, 2010).

3 Michael Emerson, One market, one money : an evaluation of the potential benefits and costs offorming an economic and monetary union (Oxford ; New York: Oxford University Press, 1992). 87. 4ibid., 67.

5ibid., 147; Paul de Grauwe, Economics of Monetary Union, Ninth edition. ed. (Oxford, United Kingdon: Oxford University Press, 2012). 26.

${ }^{6}$ Emerson, One market, one money : an evaluation of the potential benefits and costs of forming an economic and monetary union: 11,13 .

7ibid., 28, 46

8ibid., 24, 149.

${ }^{9}$ Gauti B. Eggertsson and Paul Krugman, "Debt, Deleveraging, and the Liquidity Trap: A Fisher-Minsky-Koo Approach," The Quarterly Journal of Economics 127, no. 3 (2012).

One assumes they mean that with a devalued currency, wages would take years to recover their relative purchasing power with the rest of Europe but the publication does not make this entirely clear.

${ }^{10} \mathrm{P}$. Krugman, End this depression now! , 1st ed. (New York: W. W. Norton, 2012). 45.
} 
foundation; nullifying the authors' claim that the benefits of a single currency would mean the EMU "can stand powerfully on economic criteria alone"11.

\section{The Performance of the EMU}

If a single currency is essential for prosperity in Europe, there should be measurable evidence of the prescribed benefits. An original assertion was that a single currency increases trade - so much so that economies converge and asymmetric shocks become unlikely ${ }^{12}$. A controversial paper by Rose (2000) claimed that "countries with the same currency, trade over three times as much with each other as countries with different currencies"13. Subsequent publications drastically reduced the 300\% 'Rose effect' to an average 10-15\% increase across the studies ${ }^{14}$. Baldwin et al (2008) analysed existing literature and new data, landing on as little as $2 \%$ and resting on an overall estimation of a $5 \%$ increase in trade as a result of the single currency (separate from the effect of other EMU mechanisms) ${ }^{15}$.

Interestingly they found that the lower relative price of intra-Eurozone trade could be attributed to the pro-competition effects of the EU and not the elimination of transaction costs from the single currency ${ }^{16}$. Their argument was that, if trade had increased because of eliminated transaction costs, there would be significant trade diversion which was not apparent from their findings. Instead, the increased trade through pro-competition was attributed to an increase in price sensitivity between players - both buyers and sellers - now more interconnected through EU prerogatives ${ }^{17}$. After ten years of review, the EMU's effect on trade appears to be disappointing - certainly in comparison with the enthusiasm of the federalist Delors Committee.

The increase in growth across the Eurozone has also fallen short of the pre-Euro hype $^{18}$. After climbing to just below 3\% for 1998-9, growth across the Eurozone reached a high of $3.8 \%$ in 2000 before falling to $2 \%$ in 2001 and $0.9 \%$ in 2002 , with 3\% in 2006-7 being the highest point after 2000. The central countries actually led the poor growth results with the vast majority of $+4 \%$ growth in that period occurring in smaller economies that benefited disproportionately from linking with

\footnotetext{
${ }^{11 E m e r s o n, ~ O n e ~ m a r k e t, ~ o n e ~ m o n e y ~: ~ a n ~ e v a l u a t i o n ~ o f ~ t h e ~ p o t e n t i a l ~ b e n e f i t s ~ a n d ~ c o s t s ~ o f ~ f o r m i n g ~ a n ~ e c o n o m i c ~}$ and monetary union: 29.

12.J. Frankel and A. Rose, "The Endogeneity of the Optimum Currency Area Criteria," Economic Journal 108, no. 499 (1998); Leila Simona Talani, The future of EMU (Basingstoke England ; New York: Palgrave Macmillan, 2009). 115 .

${ }^{13}$ Andrew K. Rose, Ben Lockwood, and Danny Quah, "One Money, One Market: The Effect of Common Currencies on Trade," Economic Policy 15, no. 30 (2000): 17.

${ }^{14}$ Richard E. Baldwin, In or Out: Does It Matter? An evidence-based analysis of the Euro's trade effects, (London: Centre for Economic Policy Research, 2006), http://www.cepr.org/pubs/books/P178.asp; Richard E. Baldwin and Charles Wyplosz, The economics of European integration, 3rd ed. (Maidenhead: McGraw-Hill Higher Education, 2009); Andrzej Cieślik, Jan Jakub Michałek, and Jerzy Mycielski, "Measuring the trade effects of the euro in Central and Eastern Europe," The Journal of International Trade \& Economic Development 21, no. 1 (2012); J. Frankel, "The Estimated Trade Effects on the Euro: Why Are They Below Those from Historical Monetary Unions among Smaller Countries?," in Europe and the euro, ed. Alberto Alesina and Francesco Giavazzi (Chicago: University of Chicago Press, 2010); Rose, Lockwood, and Quah, "One Money, One Market: The Effect of Common Currencies on Trade."

${ }^{15 R i c h a r d ~ E . ~ B a l d w i n ~ e t ~ a l ., ~ " S t u d y ~ o f ~ t h e ~ I m p a c t ~ o f ~ t h e ~ E u r o ~ o n ~ T r a d e ~ a n d ~ F o r e i g n ~ D i r e c t ~ I n v e s t m e n t, " ~(B r u s s e l s: ~}$ European Commission), 42, 128.

16ibid., 128.

17ibid.

${ }^{18}$ Talani, The future of EMU: 171-5.
} 
larger economies. Furthermore, nations experienced booms individually, some sustainable, others fuelled by credit bubbles ${ }^{19}$.

Unemployment results have been consistent with the low growth figures. The 10\% average in 1995 fell to around 8\% in 2001 and 2002 before rising to around 9\% until the bubble brought it down to $7.4 \%$ in 2008. After the crisis, unemployment climbed to $8.7 \%$ in 2009 and then has been higher than $10 \%$ from 2010 onwards. Unemployment in the EU, far from being structurally lowered, has trended with the investment curves, reaching its lowest ebbs in 2001 (the honeymoon period - a credit boom as interest rates converged with low German rates) and 2008 (the peak of the credit and housing bubbles). The aim of relative full employment (below 5\%) has not been achieved and indeed countries with statistically high unemployment seem to have retained high unemployment whilst neither Germany, France nor Italy achieved a sub-6\% result until Germany in 2012 (having benefitted substantially from the crisis $)^{20}$.

To summarise, the performance of the single currency and EMU has been far below the expectations expounded by pan-European federalists. Despite poor economic fundamentals, intra-industry trade has increased but not so dramatically as to structurally decrease unemployment, increase growth, converge economies and offset the risks of asymmetric shocks ${ }^{21}$. These factors demonstrate that the current incarnation of the single currency is not essential for prosperity in Europe and a greater understanding of how currency unions can be improved is required.

\section{The Theory of Optimum Currency Area}

The theory of 'Optimum Currency Area' (OCA) should have been more strongly emphasised in the design phase of the single currency. This is the theory that asserted that Europe was not a natural jurisdiction for a single currency ${ }^{22}$. OCA theory was championed by Mundell (1961) who articulated how single currencies were most effective only if states could maintain between themselves either flexible wages or labour mobility ${ }^{23}$. For example, if an asymmetric shock occurred, such as increased demand for German products instead of French, and France could not increase competitiveness (by forcing a reduction in wages or wage claims reducing as French workers moved to Germany), then France would be unable to avoid a recession as unemployment climbs, consumer spending falls, government tax receipts fall, government spending increases, interest rates increase, government debt increases and sovereign risk increases. If France was not part of a currency union, its currency could fall and thus labour costs reduce and competitiveness would increase without any fall in nominal wages ${ }^{24}$. France would also be considered less of a default risk because, as a last resort, the French central bank could always print more Francs to pay its debts.

\footnotetext{
19European Commission, "Real GDP Growth Rate," Eurostat,

http://epp.eurostat.ec.europa.eu/tgm/table.do?tab=table\&init=1\&plugin=1\&language=en\&pcode=tecoo115.

${ }^{20}$ European Commission, "Unemployment Rate," Eurostat, http://epp.eurostat.ec.europa.eu/.

${ }^{21}$ Grauwe, Economics of Monetary Union: 53.

${ }^{22}$ J. Manolopoulos, Greece's 'odious' debt : the looting of the Hellenic Republic by the Euro, the political elite and the investment community (London ; New York: Anthem Press, 2011). 42.

23 Robert A. Mundell, "A Theory of Optimum Currency Areas," The American Economic Review 51, no. 4 (1961); Grauwe, Economics of Monetary Union: 4-5.

${ }^{24}$ Grauwe, Economics of Monetary Union.
} 
The theory of OCA was expanded by Kennen (1969) who argued that an OCA also requires some 'fiscal integration' such as an increase in spending or capital transfer from the growth/surplus area to the recession/deficit area 25 . This occurs automatically, for example, in Australian federal tax and welfare systems. These conditions were not met by Europe and were not adequately addressed in the arguments put forward in the Delors Report, One Market, One Money and the subsequent Maastricht Treaty ${ }^{26}$. A different design, incorporating some of the mechanisms to be explored later, may have worked; in fact, the crisis has uncovered the many challenges hindering the evolution of the Eurosystem towards prosperity.

\section{The Causes of the Crisis}

The causes of the Euro-crisis result from the actions of Germany, the central banking system and the unaddressed flaws in the single currency design. This leads to a broader conclusion that the applied ideological doctrines were manifestly destabilising and both contributed to the crisis and hinder an acceptable resolution. The crisis originated from the failure of Europe to converge into an OCA, largely caused by Germany's choice to retain its low wages policy after the launch of the Euro. This amounted to ongoing trade intervention but it was not acknowledged to be a significant trade barrier to be eradicated by the integration process. Therefore Germany initiated the huge trade imbalance and a subsequent imbalance of payments between the centre (mostly Germany) and the periphery (including the socalled 'PIIGS' states, Portugal, Ireland, Italy, Greece, and Spain').

Not letting wages and prices rise had three knock-on effects: peripheral nations struggled to compete for labour; those peripheral nations could not therefore export enough to balance their trade with Germany which led to their increasing debt needed to maintain domestic demand (like France in the OCA example previously); and Germany's savings glut (the obverse of their trade surplus) provided the peripheral nations with abundant credit to fuel the asset bubbles needed to maintain consumption and employment ${ }^{27}$. It is important to remember that wages flexibility is a condition of Mundell's OCA; hence with Germany preventing wages rising, labour mobility was further undermined as workers were less attracted to Germany ${ }^{28}$.

\section{The European Central Bank (ECB)}

The next most important causes of the crisis were the "bad policy choices by the ECB" and its abject failure to heed warnings about the unsustainable movement of capital from the centre to the periphery ${ }^{29}$. The central problem was a lack of regulatory supervision with interest rates in the peripheral nations being incorrectly

\footnotetext{
25P. Kenen, "The Theory of Optimum Currency Areas: An Eclectic View," in Monetary problems of the international economy; [papers and discussions], ed. Robert A. Mundell and Alexander K. Swoboda (Chicago: University of Chicago Press, 1969).

${ }^{26}$ European Commission, "Report on Economic and Monetary Union in the European Community," (1989).

- Portugal, Ireland, Italy Greece and Spain

${ }^{27}$ For a thorough analysis of the 'imbalance of payments' impact see Chapter 6 of Michael Pettis, The great rebalancing : trade, conflict, and the perilous road ahead for the world economy (Princeton: Princeton

University Press, 2013); Brendan Brown, Euro crash : the exit route from monetary failure in Europe, 2 nd ed. (Houndmills, Basingstoke, Hampshire ; New York: Palgrave Macmillan, 2012). 13.

${ }^{28}$ Grauwe, Economics of Monetary Union: 5; Krugman, End this depression now!: 169.

${ }^{29}$ Brown, Euro crash : the exit route from monetary failure in Europe: 13, 127.
} 
priced too low because "membership of the EMU appeared to confer to peripheral countries the creditworthiness of Germany at a single stroke ... [and] international financial markets implicitly assumed that members of EMU would not go bankrupt"3o. Perceptions of higher justified wages and stellar growth were actually fuelled by capital inflows as debt. This led to an environment where "ECB officials wrongly diagnosed many of the symptoms of rising temperature in credit markets as indicators that the euro was indeed taking off as international money and that euro financial market integration was flourishing" ${ }^{31}$. Had OCA theory been better understood and the risks of currency union effectively communicated by officials early on, markets would have been motivated to correctly price the risk of trade imbalances and any 'sudden stop' liquidity shock. Thus the premium for sovereign default risk would have been higher and peripheral nations would not have been afforded the low risk status that fuelled excessive speculation.

\section{Neo-Euro-Liberalism}

A vital aspect of the Eurozone crisis is the ideology of neoliberalism embedded in the 'Washington Consensus' economic orthodoxy32. This ideology led European leaders to assume that as long as prices were maintained across the economy, markets could be trusted to allocate capital with minimal regulatory supervision. It advocated wholesale deregulation of the banking sector, fostered the belief that the financialisation of societies presented no inherent dangers and that the everincreasing prevalence of complex financial products had created risk-free securities 33 . Stiglitz represents a more balanced economic perspective which counters pro-market dogma with the caveat that "whenever markets have imperfect information and incomplete risk, the markets are almost never efficient [and] are also not stable" 34 .

Brown observes that "the ECB was evidently in the same intellectual culture as the Bernanke/Greenspan Federal Reserve (and Bank of England), in which temperature swings in asset and credit markets were outside the range of concern except in so far as they had implications for the inflation target" 35 . The same complex financial products - CDOs and CDFs - that hid junk US sub-prime mortgages from investors by packaging them up with other securities, appeared in Europe and, along with unjustified AAA ratings on Spanish mortgages, these created a volatile and polluted inter-banking system ${ }^{36}$. Goldman Sachs worked with Greece to falsify Greece's debt levels; malfeasance that eventually triggered the perceived spiralling risk of sovereign default and bank failure. Overall, the neoliberal ideology of deregulation

\footnotetext{
$3^{30}$ Costas Lapavitsas and Eustache Kouvélakis, Crisis in the Eurozone (London: Verso Books, 2012). 91. ${ }^{3}$ Brown, Euro crash : the exit route from monetary failure in Europe: 43.

${ }^{32}$ For an explanation of the neoliberal Washington Consensus see Manolopoulos, Greece's 'odious' debt : the looting of the Hellenic Republic by the Euro, the political elite and the investment community: 178.

33Lapavitsas and Kouvélakis, Crisis in the Eurozone: 57; Krugman, End this depression now!: 54.

34Joseph E. Stiglitz, "Macroeconomics, Monetary Policy, and the Crisis," ed. Olivier Blanchard and ebrary Inc., In the wake of the crisis leading economists reassess economic policy (Cambridge, MA: MIT Press,, 2012),

http://ezproxy.lib.monash.edu.au/login?url=http://site.ebrary.com/lib/monash/docDetail.action?docID=10534 381. 33 .

35Brown, Euro crash : the exit route from monetary failure in Europe: 74, 79.

'Collateralised Debt Obligations' and 'Credit Default Swaps'

${ }^{36}$ Brown, Euro crash : the exit route from monetary failure in Europe: 102; Lapavitsas and Kouvélakis, Crisis in the Eurozone: 48.
} 
and trust in markets shaped the Eurozone's non-interventionist policy which in turn fostered a response that was similarly ideological and flawed 37 .

\section{The Neo-Liberal Response}

The Eurozone crisis was triggered by the realisation of market failure and a resulting liquidity shock. Markets withdrew capital from Ireland, due to the bursting of the housing bubble and from Greece because of the economy's financial mismanagement. The connectedness of interbank markets meant that contagion spread, hitting the inflated peripheral economies the hardest. Despite Spain having less public debt than the UK, its membership in the single currency meant it could not service debt in a crisis by printing a national currency so the markets viewed it as a sovereign risk. This created the self-fulfilling "doom loop" whereupon the fear of default inspired capital flight which in turn increased the risk of default 38 .

Prior to the crisis, Ireland and Spain's financial management had been vocally supported by the EU institutions and financial commentariat. Suddenly, neoliberals forced a change in the narrative to a 'morality tale'39 interpretation of the crisis where the "conventional wisdom of the mainstream media and politicians" declared the crisis to be the fault of "lazy' and 'profligate' southerners" who are over-spending debtors (with no blame for careless creditors or the single currency's design) ${ }^{40}$. This enabled the major financial and political institutions to pressure governments in the periphery to bail out their banks, implement 'austerity' and transfer the enormous losses of private enterprises onto sovereign governments and their taxpayers. However, austerity policies are flawed and condemn countries to a "downward spiral of stagnating economies and faltering real incomes" with governments then becoming less able to use their capacities of direct intervention to stimulate productive activity. 41

Austerity became the unquestionable doctrine in the political discourse and the IMF, with its Washington Consensus manifesto, demanded harsh public-sector cuts and privatisations in return for its emergency loans. ECB President Trichet approved, declaring that "the idea that austerity measures could trigger stagnation is incorrect" and that "balanced public finances inspires confidence and confidence will foster growth" ${ }^{2}$. Trusting bond markets to provide liquidity and restore growth was fraught with danger as the unemployment/stagnation problem proved to have a far greater impact on confidence43. Labelled by opponents as the 'confidence fairy', this approach was wholly unfounded because 'expansionary austerity' policies - inspired by Alberto Alessina's 1998 article44 - have clearly been shown to have little or no

\footnotetext{
37 Lapavitsas and Kouvélakis, Crisis in the Eurozone: 162.

$3^{8}$ P. Krugman, "Revenge of the Optimum Currency Area," in Macroeconomics Annual, ed. D. Acemoglu, Parker,

J., Woodford M. (National Bureau of Economics Research, 2012), 9.

39 Krugman, End this depression now!: 179.

${ }^{40}$ Lapavitsas and Kouvélakis, Crisis in the Eurozone: xix.

${ }^{41}$ David Marsh, The Euro : the battle for the new global currency, New ed. (New Haven, Conn. ; London: Yale

University Press, 2011). 254.

${ }^{42}$ Krugman, End this depression now!: 188.

43 Lapavitsas and Kouvélakis, Crisis in the Eurozone: 121.

44 Alberto Alesina, Silvia Ardagna, and Jordi Galí, "Tales of Fiscal Adjustment," Economic Policy 13, no. 27

(1998).
} 
expansionary effect45. Indeed the IMF issued a mea culpa in 2010 finding that austerity actually depresses the economy and business and consumer confidence ${ }^{46}$.

The bailout and austerity in Greece is an example of dominant power structures serving a pro-investor, neoliberal agenda as "the rhetoric of European leaders was about saving the European Monetary Union by rescuing peripheral countries, [yet] the underlying aim was to deal with the parlous state of the banks at the core" 47 . This can be evidenced by the fact that "the majority [approximately 80\%] of IMF money received to date has gone to bail out foreign creditors" 48 . The pressure on governments to sell assets cheaply benefited the private sector by ensuring a huge capital gain for corporations when asset values recover. Austerity, being designed to "compress demand, while cutting wages and paving the way for the introduction of a radical liberalisation programme", ensures that "the role of the state ... [is] redefined, also promoting a more regressive distribution of income that would appease the ruling social layers in the Eurozone" 49 . This might explain the ease with which such an unsupported economic doctrine could permeate the upper echelons of Eurozone leadership and filter down through the press and public channels of discourse.

\section{How To Repair The Eurozone: Financial Stability}

There are a range of proposed doctrinal changes and new mechanisms that should be instituted to solve the ongoing crisis and move Europe towards becoming an OCA. First and foremost, if the ECB relinquished its single mandate on prices and declared an explicit 'dual mandate' to include financial stability through full employment then it would have many more mechanisms at its disposal to correct underlying structural imbalances50. As Stiglitz argues, "the perspective that low and stable inflation leads to a stable economy and fast economic growth was never supported by either economic activity or evidence, and yet it became a main tenet of central bank doctrine" 51 . There has been little acknowledgement that the loss in productive capacity (the 'output gap') resulting from systemic monetary failure is now trillions of dollars, far more than any loss resulting from potential inflation if the ECB had lent to governments earlier52.

With more mechanisms at its disposal, the ECB could have been (and should now become) the 'lender of last resort' to offset the inability of individual nations to print their own currency in a liquidity crisis. This would have provided a guarantee of liquidity, similar to the US Federal Reserve or the Bank of England, and avoided the initial panic in the markets that triggered the crisis53. The ECB, modelled on the Bundesbank, is prohibited from buying government bonds so as to avoid 'moral hazard'54. Given that the ECB began purchasing government bonds in the secondary

\footnotetext{
45 Krugman, End this depression now!: 196-201.

46 IMF, "World Economic Outlook: Coping With High Debt and Sluggish Growth."

47Lapavitsas and Kouvélakis, Crisis in the Eurozone: 108.

48 Manolopoulos, Greece's 'odious' debt : the looting of the Hellenic Republic by the Euro, the political elite and the investment community: 124.

49Lapavitsas and Kouvélakis, Crisis in the Eurozone: 121.

$5^{\circ}$ Brown, Euro crash : the exit route from monetary failure in Europe: 16-17.

${ }^{51}$ Stiglitz, "Macroeconomics, Monetary Policy, and the Crisis," 35.

$5^{2}$ ibid.

53Grauwe, Economics of Monetary Union: 117.

${ }^{54}$ Cini and Pérez-Solórzano Borragán, European Union politics; Lapavitsas and Kouvélakis, Crisis in the Eurozone: 36, 42, 168.
} 
market in 2010, it has effectively created: an unofficial dual mandate (recognising the destabilising effect of a polluted monetary system); a supposed moral hazard anyway (after forgoing years of increased confidence by refusing to provide an official guarantee); and an indirect form of minor fiscal transfer as the richer states contribute more to financing the ECB55.

The ECB's actions highlight the fact that there was a need all along for some kind of fiscal transfer to foster an OCA and, above all, protect against crises. There are three main ways that a fiscal or transfer union could occur: one, a full fiscal union where the power to tax and spend in major areas is ceded to the EU government; two, governments contributing more to institutions that would lend to nations; or three, a system of jointly issued debt called E-bonds, established so that nations can issue securities that carry the lowest interest rate. Option one is unachievable politically but options two and three hold great promise for the monetary stability of Europe. Option two might comprise the ECB (in a lender of last resort capacity), the recently established European Financial Security Facility (EFSF)56. or some kind of European Monetary Fund (EMF), any of which could provide liquidity for productive investment or crisis bailouts.

Option three, a transfer union via a 'Eurobond' or 'E-bond', has been prevented because of concerns over moral hazard and rich nations subsidising the failures of poorer nations57. This perspective demonstrates a 'double moral-hazard standard' because it ignores the inherent moral hazard in bailouts where banks have been able to undertake risky lending and then pass on the cost of their failure to the taxpayers in peripheral countries. Moral hazard for governments could be combated with a tranche system incentivising low public debt by rewarding nations with debt below a certain level (e.g. 60\%) with the lowest interest rate ${ }^{58}$. Furthermore, the budgetary supervision that is now being undertaken as part of the European Fiscal Compact will have a greater chance of disciplining overspending governments. Such a joint issue of debt would also show greater confidence in the Euro, leading it to potentially grow into a reserve currency and offset Germany's interest rate increase with the fifty basis point premium enjoyed by the US 59 .

The ECB should also seek to increase its use of intervention mechanisms such as reserve ratios and independent regulatory bodies to regulate securities and pressure nations to remove destabilising policies. If the ECB had increased the reserve requirements for certain peripheral banks and regulated the trade of securities like CDOs and CDSs, it could have better tailored monetary policy from nation to nation, meaning fewer banks would have leveraged into the asset bubbles ${ }^{60}$. Furthermore, if the ECB was granted the direct power to vocally publicise facts about OCA imbalances, then Germany could be pressured to let its wages rise and thereby provide the demand the peripheral nations need in order to export and pay their

\footnotetext{
55Lapavitsas and Kouvélakis, Crisis in the Eurozone: 110.

56.The EFSF of $\$ 440$ billion euro is unfortunately designed with interest rates that are too high for struggling nations to catch up competitiveness - rates are some 200 basis points above German rates: Paul de Grauwe, "The Governance of a Fragile Eurozone," Australian Economic Review 45, no. 3 (2012): 255.

57 ibid., 263; Krugman, End this depression now!: 28.

${ }^{8}$ Grauwe, "The Governance of a Fragile Eurozone," 264.

59 Grauwe, "The Governance of a Fragile Eurozone," 265.

60 Grauwe, Economics of Monetary Union: 26.
} 
debts. The EMU has been "an ordeal for German workers" 61 and would be delivering them a pay rise, thus becoming a system that delivers, to people in the centre and periphery, a better share of European wealth.

\section{A Managed Economic Revival: Rejecting 'Expansionary Austerity'}

The Eurozone's structural problems of divergence and design have strikingly intensified the Greek crisis, making potential recovery strategies instructive to the rest of the troubled periphery. Like other peripheral states, the underlying uncompetitiveness and structural flaws in the Greek economy caused increasing debt levels as suddenly cheap money was used for the subsidisation of inefficient industries and household consumption ${ }^{62}$. At this stage the EU has convinced Greece to 'toughen it out'63 yet it remains to be seen whether a managed economic revival mimicking Sweden's in the early 1990 s is achievable.

A comparison between Sweden and Japan's response to their respective crises will be useful in understanding the choices for Greece. Both possessed overheated economies and asset bubbles that burst and caused the banks to fail. Japan chose to hide the extent of the crisis from its people, protect the interests of the increasingly insolvent banks, delay many years in providing bank guarantees and then found themselves in a liquidity trap that caused twenty years of stagnation. In comparison, Sweden undertook a bipartisan process of taking over banks, transparently explaining why they let some institutions fail, recapitalising banks, guaranteeing deposits for households and fiscally stimulating the weak areas of the economy to support employment and demand ${ }^{64}$. They took on heavy debt to do this and endured "large budget deficits between 1991 and 1997"65.

The question for Greece is whether the ingrained cultures and lack of trust in government (much like with Japan) will prevent a managed economic revival in the Swedish style and whether the austerity policies required by the EU and IMF will be rejected seeing they are counter-productive to rebuilding the Greek economy ${ }^{66}$. With Germans potentially voting to stop bailing out other nations and polls showing that $83 \%$ of Greeks expect more austerity, the need for drastic fiscal stimulus in order to avoid stagnation, debtor-led default or at worst a Greek exit, should be explored ${ }^{67}$.

\section{The Importance of Fiscal Stimulus}

It has been argued by Krugman and others that we have returned to an era of 'depression economics', where the great lesson is that Keynesian fiscal stimulus is the

\footnotetext{
${ }^{61}$ Lapavitsas and Kouvélakis, Crisis in the Eurozone: $4,161$.

62ibid., 96; Michael Metsopoulos and Théodore Pelagidis, Understanding the crisis in Greece: from boom to bust (New York: Palgrave Macmillan, 2011). 18-20; Lynn, Bust: Greece, the euro, and the sovereign debt crisis: 115. 63P. Krugman, "Can Europe Be Saved?," New York Times Sunday Magazine(2011), http://www.nytimes.com/2011/o1/16/magazine/16Europe-t.html?_r=2\&ref=maga\&.

64E. Bayram, A. DeWit, and S. Steinmo, "The Bumble Bee and the Chrysanthemum: Comparing Sweden and Japan's Response to Financial Crisis," in World Politics (Cambridge University Press, 2010), 30; Lars Jonung, "The Swedish Model for Resolving the Banking Crisis of 1991-92: Seven reasons why it was successful.," Economic Papers European Economy, no. 360 (2009).

${ }^{65}$ Bayram, DeWit, and Steinmo, "The Bumble Bee and the Chrysanthemum:

Comparing Sweden and Japan's Response to Financial Crisis," 18.

${ }^{66}$ Manolopoulos, Greece's 'odious' debt : the looting of the Hellenic Republic by the Euro, the political elite and the investment community: 179.

${ }_{67}$ N. Stamouli, "Greece's Ruling New Democracy Widens Lead in Polls," Wall Street Journal, 27 Jan 2013.
} 
only way to avert Fischer's cycles of 'Debt-deflation' (1933) i.e. when the people stop spending to pay down debt which only compounds debt as more is needed to prop up falling demand/spending 68 . Greece is replicating the UK's experience pre-WWII where debt de-leveraging became the mantra, causing the economy to stall and debt to compound 69 . Unfortunately the current framing of debt as 'bad' creates a situation where nations are prevented from doing what the world did to get out of the Great Depression and what Sweden and recently Iceland did to spark their recovery - take on further debt, even to enormous levels, in order to spend, create demand, grow GDP and eventually pay down debt more easily. As long as it is targeted to productive initiatives in a reformed economy (not Greece yet), debt problems can be fixed with more debt.

Europe's experience with stimulus so far illustrates this point as Coenen et al show that the $\$ 200$ billion spent through the European Economic Recovery Plan "led to an increase in annualized quarterly GDP growth of up to 1.6 percentage points during the crisis"70. When asked what he would recommend for Greece, Iceland's finance minister Sigfusson, who rescued the country from the worst financial crisis in human history ${ }^{71^{\dagger}}$, said "First security for society. Then the lower and middle income classes must be protected from austerity measures. Their purchasing power must be maintained so that their consumption can contribute to the revitalization of the economy. Internationally, that is often overlooked." The true test of political efficacy is not whether reforms are feasible but whether ideologies that hinder those reforms can be overturned. Despite the controversy over the debt associated with Keynesian stimulus, "the net effect overall would be distinctly positive for the future growth and prosperity of the current membership - and for the wider world"72.

\section{Conclusion}

The Eurozone crisis has inspired greater focus on both the economic and ideological features of the EU. Overcoming dominant ideologies as they pervade governance structures and expert systems is an ongoing project and one that requires constant discussion and contestation. This paper outlined the performance of the EMU, the causes of the Eurozone crisis and potential pathways to recovery. Further study should focus on how to compel the power structures of the EU to address these inherent imbalances. If the economic solutions become established, the conclusion must be reached that large ongoing faults actually reflect large failures of governance structures - which remain up to European citizens and the wider world to solve.

\footnotetext{
${ }^{68}$ Krugman, End this depression now!: 45.

69 Marsh, The Euro : the battle for the new global currency: 254.

- In the same way that recessions compound debt burdens, growth compounds the capacity to pay off debt and, with marginally higher inflation (as is consistent with stimulus programs), lowers debt burdens and increases productive capacity.

${ }_{70}^{\circ}$ G. Coenen, R. Straub, and M. Trabandt, "Fiscal Policy and the Great Recession in the Euro Area," (European Commission, 2011), 20.

${ }^{\dagger}$ Iceland's "gross external debt had increased to over 600 per cent of GDP": IMF, "World Economic Outlook: Coping With High Debt and Sluggish Growth," 4.

72 R. P. Bootle, "Leaving the Euro: A Practical Guide," (Wolfson Economics Prize, 2012), 60.
} 